\title{
Feminist and stratification theories' lessons from the crisis and their relevance for post-Keynesian theory
}

\author{
Stephanie Seguino* \\ University of Vermont, Burlington, VT, USA
}

The many contributions of post-Keynesian economists to understanding the causes of the global financial crisis that began in 2008 could be enhanced by integrating the research by feminist and stratification economists. These groups have produced a body of work analysing trends in inter-group and intra-class inequality that led up to the crisis and theoretically inform how we assess the distribution of the negative effects of the crisis by class, race, and gender. Further, this body of work has assessed the potential for fiscal and monetary policy to promote greater equality while reducing intra-class competition and conflict.

Keywords: stratification, post-Keynesian macro models, gender, race, fiscal and monetary policy

JEL codes: $B 5, E 6, Z 13$

\section{INTRODUCTION}

The global financial crisis that began in 2008 resulted in the widespread destruction of jobs and livelihoods, with the effects disproportionately felt among subordinate racial groups and women. Mainstream analysis on the root causes of the crisis has focused on lack of regulation of the financial sector. Post-Keynesian (PK) and feminist macroeconomists (FMs), however, expanded the field of vision to consider the contributing role that growing inequality had played. PKs have tended to emphasize the size and functional distributions of income as their measure of inequality (thus, focusing on class), while feminist economists (FEs) and stratification economists (SEs) have explored the role of inter-group inequality by race and gender in the crisis. They have also analysed the race and gender implications of the effects of the crisis and subsequent macrolevel austerity policies adopted after the onset of the crisis.

FEs share with PKs a macroeconomic framework that accounts for the impact of income distribution on output and employment. The distinctive contribution of FEs that sets them apart from PKs, however, is their analysis of the supply-side effects of the crisis. This work has led to new ways to conceptualize the effectiveness and roles of fiscal and monetary policy. This paper explores those contributions, emphasizing their relationship to the emerging field of stratification economics from a macroeconomic perspective.

* Email: sseguino@uvm.edu. 


\section{INTER-GROUP INEQUALITY PRIOR TO THE CRISIS}

Among the factors that precipitated the crisis, growing inequality both within and between countries contributed to stagnant wages and low levels of aggregate demand (Seguino 2010b; Cynamon/Fazzari 2015; Stockhammer 2015). Leading up to the crisis, household indebtedness was on the rise, thus sustaining demand well into the 2000s. Carr/Jayadev (2015) provide evidence that indebtedness increased more for lowerincome households in the decade prior to the crisis. Debt financing of consumption was not simply a 'consumption binge' on the part of the poor (though it may well have been the case in middle-income families who were emulating the rich). Falling real wages for blue-collar workers, a decline in employer pension contributions, and rising medical and education costs all have placed financial pressure on low-income households, with debt financing and refinancing of mortgages a means to maintain a stable income. These conditions were met with unsustainable credit expansion and predatory mortgage lending, targeted at the most vulnerable, including women and families of color. Indeed, Dymski et al. (2013) note that these groups, which had been superexcluded from credit in the past, were super-included in exploitative sub-prime lending in the 2000s.

A missing dimension in analyses of the crisis is an understanding of the trends in intra-class inequality. While minorities and women were disproportionately the targets of predatory lending prior to the crisis, low-income whites had also been experiencing deteriorating economic conditions. This is perhaps exemplified best by Case/Deaton's (2015) study of trends in life expectancy and mortality in the United States. They provide evidence of declining life expectancy and increased mortality from 1999 to 2015 amongst non-Hispanic whites with a high-school education or less. The main causes are premature deaths due to suicide, drug overdoses, and alcohol-related liver mortality or what the authors label 'deaths of despair.' This trend is not found in Europe, perhaps related to Europe's greater regulation of labor markets and a broader social safety net.

A further trend is the downward harmonization of men's economic well-being compared to that of women. Women's employment rate relative to men's has been rising since 1991, not only in the US but also in a large number of developed and developing countries (Seguino 2016). While this may be positive news for gender equality, the trend is gender conflictive in the sense that even as the ratio of female-to-male employment rates has risen, men's employment rates in many countries have fallen. Figure 1 plots changes in the female/male (F/M) employment-rate ratio against changes in male employment rates for 1991 to 2010 . In 70 percent of the 140 countries in which the F/M employment ratios have risen over this period of time, male employment rates have fallen. This can be observed in the northwest quadrant of Figure 1, which identifies countries in which male rates have fallen and female-to-male ratios have risen. These data should not be interpreted to signify that women have substituted for men in the labor market. Pronounced occupational and industrial segregation in most countries makes substitution inelastic. A more likely cause is structural change leading to the loss of 'male' jobs, especially in manufacturing, and the expansion of jobs typically associated with women's labor (for example, health aid workers and community services workers) or with women's distress sales of labor in the informal sector. The latter is triggered by declines in male income, pushing some women into the labor market as a way to buttress family income.

Can theory help to explain the political fallout - in particular the rightward shift in politics - from these trends? Recent insights from SEs and FEs offer theoretical frameworks to explain both the contributions of inter-group inequality to the crisis and the distributional effects of post-crisis policies, in particular the adoption of austerity policies. 


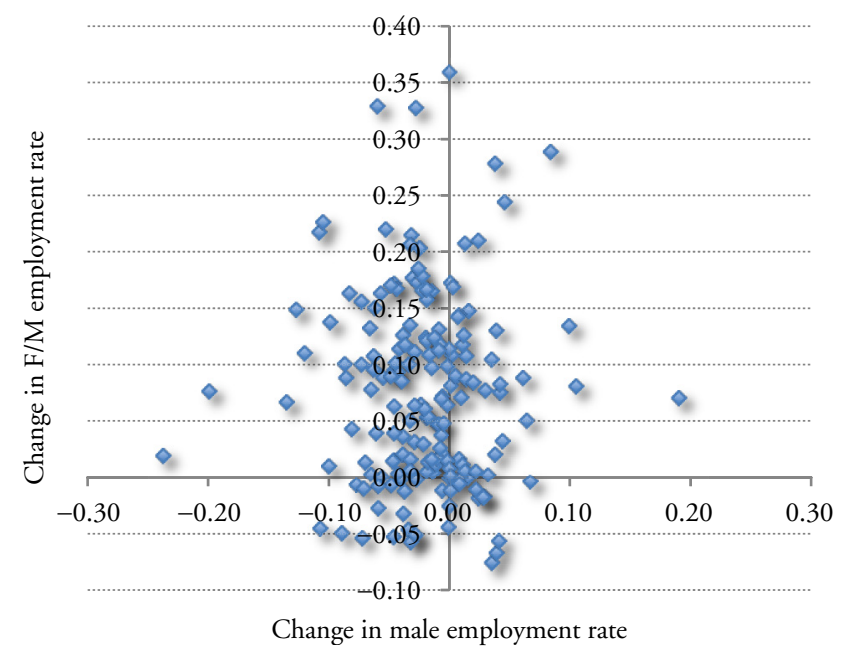

Source: Author's calculations with data from World Development Indicators online database.

Figure 1 Change in female-to-male and male employment rates, 1991-2010 (percentage points)

\subsection{Stratification economics}

Stratification economics analyses the structural and institutional processes influencing the reproduction of hierarchy and thus inter-group inequality, emphasizing in particular the implications for race and gender inequality (Blumberg 1984; Darity et al. 2017). Stratification processes in most industrialized countries are characterized by the dominance of whites and males, with women and racial/ethnic 'minorities' the subordinate groups.

Stratification economics identifies two key mechanisms by which intergroup inequality is perpetuated: exclusion and exploitation. Exclusion, otherwise known as opportunity hoarding, is the dominant group's monopolization of opportunities and prized positions or resources. One example is white males' privileged access to and overrepresentation in the primary sector, with women and people of color more likely to be segregated (crowded) into jobs in the secondary sector. Exploitation is the extraction of value by the dominant group of the work effort of subordinate groups.

Stratification by race and gender is pronounced, and has implications for collective action on the part of the dominant group that may override class concerns. It is useful to characterize the dominant group's mental framework that can lead to intra-class conflict. This mental framework includes a sense of superiority over subordinate groups and of proprietary claim to aspects of economic and social privilege and advantage (Blumer 1958). Viewed through this lens, white male backlash against people of color, immigrants, and women can be understood as a response to the declining economic fortunes of this group, whereby loss of privilege is experienced as discrimination. It is useful to underscore, however, that the worsened economic conditions experienced by members of the dominant group (whites, males, the native born) reflects a downward harmonization towards, but not to, the economic condition of subordinate groups. In other words, racial and gender gaps persist, even as members of the dominant group increasingly face the economic insecurity that subordinate groups have long faced. 
Seen in this light, stratification economics offers a lens to understanding the relationship between macroeconomics and inter-group inequality by race and gender. While it is true that workers in general suffer the negative effects of unemployment during economic downturns, stratification economics emphasizes that capitalism produces good jobs, bad jobs, and no jobs. Racial and gender hierarchies slot subaltern groups into the bad jobs and job shortages. Macroeconomic conditions influence the extent of race and gender animus and inequality, with the effect that during hard economic times, racial and gender hostility worsen (Darity et al. 2006).

Applying this to the pre-crisis period, white men's economic fortunes have eroded, leading to their downward harmonization to the economic circumstances women and subordinate racial groups have long faced. This is due to both the shrinking of the social safety net as well as economic restructuring, in part induced by globalization, that have contributed to stagnant wages, diminished job opportunities, and the growing precariousness of work when it can be found. White men's economic decline, instead of leading to class solidarity with similarly situated people of color and/or women, exacerbates racial and gender tensions and has contributed to the rightward political shift in many industrialized countries. We use this lens to analyse the effects of the crisis and subsequent economic events.

\subsection{Feminist economics}

What might we learn from feminist economics that has been missed in much of the PK academic and policy literature? In addition to conducting research on gendered trends in the labor market that have implications for the labor share of income, feminist economics has accumulated 25 years of research and analysis on social reproduction that is relevant for PK macroeconomists modeling the supply side of the economy. I briefly allude to this body of work here, describing in more detail in later sections how these approaches have been utilized to understand the effects of austerity and can contribute to informing policy proposals that are equity- and growth-enhancing.

FEs have identified the effects of globalization with women integrated into labor markets, but in an inferior position - that is, in jobs that pay lower wages, have a shorter job ladder, and have less training than male jobs. In some countries, job segregation is reflected in women's crowding into labor-intensive export industry employment, with men in more capital-intensive and/or non-tradable industries (Standing 1989; Kucera/Milberg 2000; Blecker/Seguino 2002; Seguino 2010a).

More recently, Seguino/Braunstein (2018) found evidence that gender job segregation has increased substantially from 1991 to 2015 in both developed and developing countries, with women increasingly excluded from 'good' jobs in the industrial sector. Two key determinants of this trend are structural change, related to the rising capital-labor ratio, and the ratio of female-male labor force participation rates - indicative of 'crowding' and exclusion from the shrinking number of good jobs. The authors further found that the crowding of women into lower-quality jobs has a negative effect on workers as a whole by contributing substantially to the falling labor share of income.

In addition to contributing to the understanding of how gender dynamics have impacts on the class distribution of income, feminist economics has illuminated the importance of care work, or social reproduction, recognizing that labor is a produced factor of production requiring years of family investment of time as well as money (Folbre 1994). Care work is economically necessary work, whether paid or unpaid. Three aspects of this work are relevant to macro models. First, the daily aspects of social reproduction contribute to current productivity by helping workers to replenish themselves each day to return to their paid jobs. Second, care work serves as a long-term investment in children that has a positive effect 
on a country's future productive capacity. This work promotes the development of human capacities, a concept that is broader than human capital. Braunstein et al. (2011), for example, describe human capacities as qualities that make human beings economically effective, such as emotional maturity, patience, self-confidence, and the ability to work in teams. Finally, care work is a highly gendered activity, with women providing the bulk of the labor. The intensity of unpaid work increases during economic downturns, disproportionately burdening women. This is because, as family incomes decline due to higher unemployment, families substitute domestic production of goods and services (that is, unpaid care work at home) for market goods and services. Moreover, as men lose jobs during recessions, women may engage in 'distress sales' of labor, joining the labor market albeit in low-wage jobs to replace a portion of lost household income.

\section{THE CRISIS THROUGH A FEMINIST/STRATIFICATION LENS}

Early on, some called the Great Recession a 'mancession' (Wall 2009). That observation was predicated on job losses during the onset of the recession in two male-dominated industries: construction and manufacturing. What a number of observers missed however was that, among male workers, the effects were disproportionately felt by men of color and/or foreign-born men. In the US, the percentage point increase in black and Hispanic unemployment was much higher than for whites (Figure 2). Specifically, the increases in unemployment rates from 2007 to 2010 (the year that unemployment peaked for all groups) for blacks, Hispanics, and whites respectively, were 7.7, 6.9, and 4.6 percentage points. Further, single mothers were substantially more likely to become unemployed as the crisis set in than either married men or women (Figure 3).

In Europe, similar processes of stratification were at work. Figure 4 presents the 2012 ratio of female-to-male unemployment rates of the native-born, and the unemploymentrate ratio of extra-EU27 workers to that of native-born males. Gender differences are far less pronounced than racial/ethnic differences, just as in the US. Of note is that, despite the anxieties of native-born workers in a number of EU countries that they were being displaced by immigrants, in fact the non-native-born suffered greater job losses in response to the crisis.

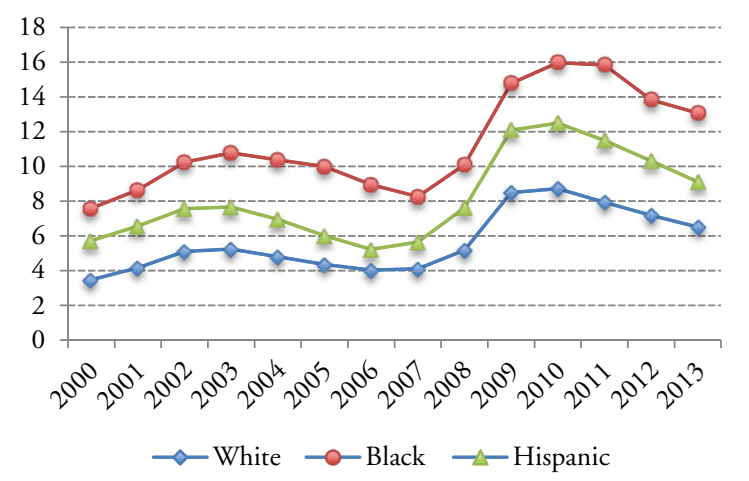

Source: Current Population Survey, US Department of Labor, US Bureau of Labor Statistics.

Figure 2 US annual unemployment rates by racelethnicity, 2000-2013 


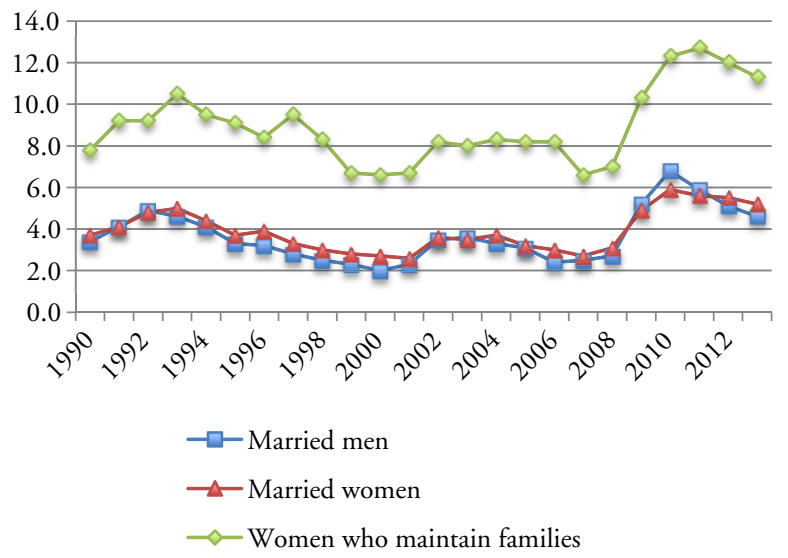

Source: Current Population Survey, US Department of Labor, US Bureau of Labor Statistics.

Figure 3 US monthly unemployment rates by marital status, 1990-2013

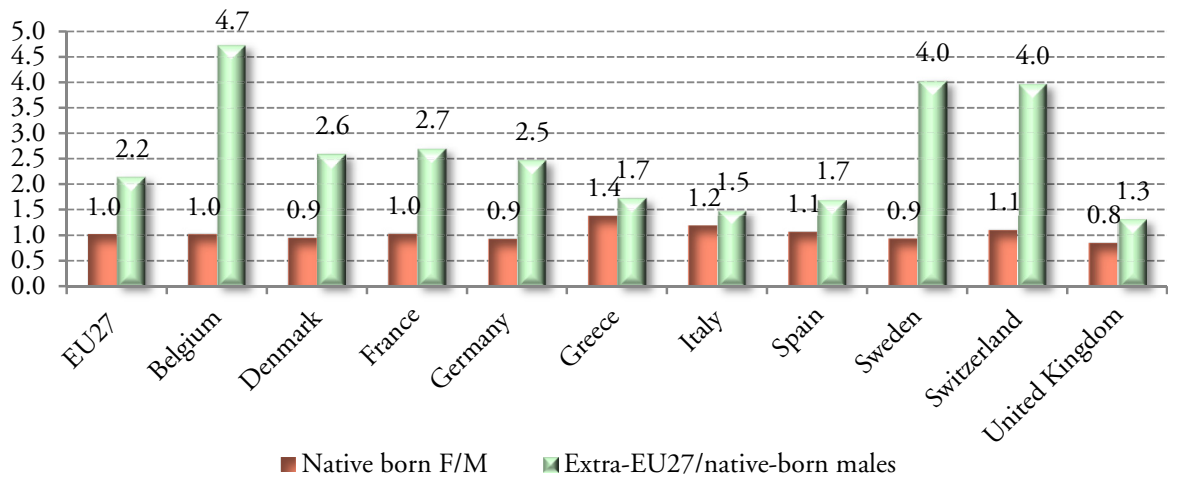

Source: Author's calculations using OECD data (https://stats.oecd.org/).

Figure 4 Unemployment-rate ratios relative to native-born men, 2012

As the crisis wore on in Europe, a number of governments adopted austerity measures to combat the growing deficits that piled up from their fiscal stimulus programs (Ortiz/ Cummins 2013). FEs have extensively analysed the impact of austerity on women and those they care for, especially children (Karamessini/Rubery 2013; Women's Budget Group 2013; Fukada-Parr et al. 2015). Budget cuts disproportionately affected the social-service sectors. As a result, austerity had negative effects not only on demand for female labor but also on access to services that support women in their role as carers, thus compelling them to increase their unpaid domestic labor ${ }^{1}$ in order to compensate for social-service cutbacks.

1. See Berik/Kongar (2013) and Bahçe et al. (2013) on the gendered effects of the crisis on time use and unpaid labor. 
The UK Women's Budget Group has done the most extensive quantitative work on the effects of austerity, based on simulations using the Landman Economics tax-benefit model. Table 1 reproduces the Women's Budget Group (2017) study of the cumulative effects of the austerity budget proposed by the UK government. The table outlines the effects of changes in taxes and benefits by gender and household quintile over the period 2010-2020. Among all families with children, lone-mother family incomes will decline 13.8 percent by 2020 , compared to a 4.7 percent decline for males in two-adult households and 10.8 percent for women in two-adult households. Figure 5 shows that the UK government's austerity measures not only result in the largest decline in household income for the poorest, but also that the effects are disproportionately large for black and Asian households as compared to white households.

These findings are perhaps not surprising, given persistent gender and racial inequality over time. That said, a stratification/feminist analysis underscores that intra-class conflict is dynamic - and confounding in its complexity. White male economic insecurity and

Table 1 2010-2020 cumulative impact of changes in taxes and benefits by gender and household income quartile (percentage of net income)

\begin{tabular}{lcrc}
\hline & \multicolumn{2}{c}{ Single } & \multicolumn{2}{c}{ Couples } \\
\cline { 2 - 4 } \cline { 3 - 4 } & Mothers & Fathers & Mothers \\
\hline All & $-13.8 \%$ & $-4.8 \%$ & $-10.8 \%$ \\
Poorest 20\% & $-17.6 \%$ & $-18.4 \%$ & $-26.9 \%$ \\
2nd 20\% & $-14.7 \%$ & $-9.1 \%$ & $-17.9 \%$ \\
3rd 20\% & $-12.7 \%$ & $-4.3 \%$ & $-8.7 \%$ \\
4th 20\% & $-11.5 \%$ & $-2.0 \%$ & $-5.5 \%$ \\
Richest 20\% & $-7.4 \%$ & $-1.1 \%$ & $-5.6 \%$ \\
\hline
\end{tabular}

Source: Women's Budget Group (2017: table 2.3).

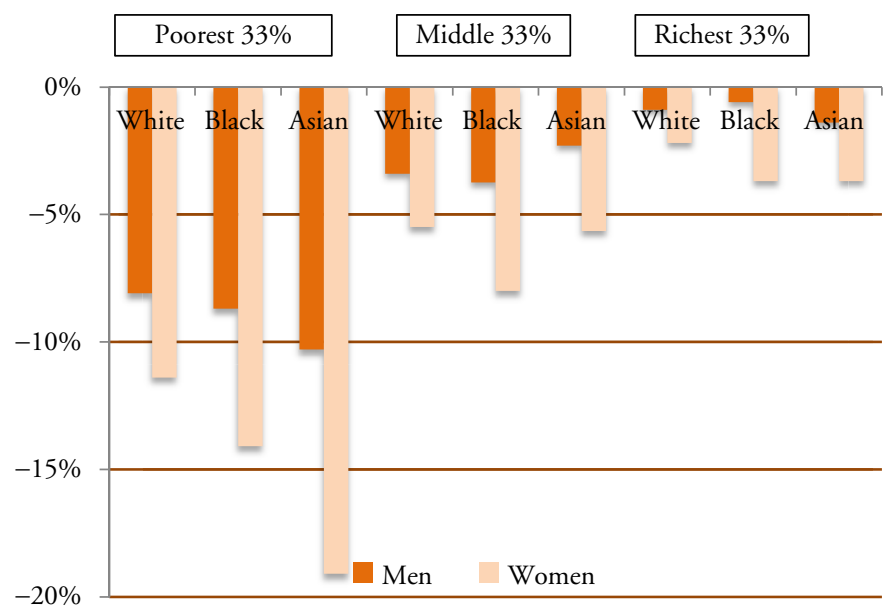

Source: Women's Budget Group (2017: table 2.1).

Figure 5 2010-2020 cumulative individual impact of changes in taxes and benefits by household income groups, gender, and ethnicity 
downward harmonization in particular fuel racial/ethnic/immigrant animosity and gender backlash. This has political ramifications that contribute to disenfranchized males from dominant groups supporting far-right political parties and politicians such as La Lega in Italy, Trump in the US, and the effect of the UK Independence Party (UKIP) on the Conservative Party in the UK, among others. In past years, some from a Marxist tradition might have called this 'false consciousness.' Today, feminist and stratification research helps us to understand that intra-class conflict - that is, the fracturing of the working class - can at least in part be explained by these intra-class dynamics in labor markets and social spending. Dominant males' economic status has fallen closer to that of the groups they eschew as inferior and less deserving. But even beyond these considerations, several contributions of feminist and stratification economics in the post-crisis period are worth PK economists integrating into their macro models and policy analysis. Those lessons are taken up in the next section.

\section{THREE LESSONS FROM THE CRISIS}

FEs and SEs have generated a rich literature resulting in three salient lessons from the Great Recession that began in 2008. Their work has implications not only for heterodox macro modeling but also for policy. Indeed, the work of these groups has expanded and changed the contours of heterodox fiscal and monetary policy analysis.

\section{Lesson 1 Economic insecurity and cuts to social spending have long-term negative effects on buman development and productivity.}

FEs have a long record of studying the distributional effects of macroeconomic policy, beginning with the critique of structural adjustment (SA) in the 1980s. That research revealed the disproportionate effects of SA on women, and, in particular, poor women and girls (Benería/Feldman 1992; Elson 1995). Two components of SA policies have been linked to gender unequal outcomes. Public expenditure cuts, especially in social services and health, increased women's unpaid care burden at home (and thereby limited the time that women could spend in paid work). In addition, because women tended to be overrepresented in public-sector employment, they experienced disproportionate job losses with those cuts.

This is significant because women's and men's preferences on resource allocation have been shown to differ (Folbre 1986; Haddad et al. 1997; Doss 2013). Women tend to spend a larger share of their income and resources on children's well-being while men tend to spend more of family income on non-essentials and luxury goods. As women's income (and, as a result, bargaining power) declines, the less likely are their preferences to be reflected in household allocation of resources. This research illuminates the link between macro-level policy, social reproduction, and children's well-being with implications for long-run productivity growth.

The findings of this earlier research informed the work of FEs in analysing the effects of the Great Recession of 2008 and the subsequent adoption of austerity policies in several countries. The direct effects of the crisis and austerity on women's relative employment were noted in the previous section. The added value of a feminist economics lens extends to research that underscores that cuts to social spending along with economic instability have long-term negative effects on human development and productivity. The transmission mechanism is through the negative impact on livelihoods and access to publicly funded social services of women and people of color, leading to reductions in investments in children's health, education, and other aspects of well-being (Henrici et al. 2010; Ortiz/Cummins 2013; Currie et al. 2015). 
The effects of the Great Recession in rich countries, in other words, mirror those of the structural adjustment policies of the 1980s and 1990s affecting developing countries.

A large body of evidence also links women's health to children's development, with long-lasting effects on children's cognitive skills and, as a result, a country's long-run productivity growth (Agénor et al. 2010; Almond/Currie 2010). It is this intergenerational transmission from parents - and particularly mothers - to children's cognitive development that is of significance for modeling long-run economic growth. Ironically, neoclassical economists who focus almost exclusively on the supply side have made greater strides in integrating these findings into macro models than have PK economists.

In addition to the research that demonstrates how macro policies that disproportionately affect women contribute to hysteresis through their effects on children, the findings of brain neuroscience are of relevance. That research identifies the neuroscience of poverty and economic insecurity, by which economic deprivation limits the brain development of children. Brain areas that are most affected are those related to memory and language, emotional control, and self-regulation and learning. In general, everyday hardships associated with poverty, which cause neurobiological changes, have a substantially bigger effect on the poor than on the wealthy. Children's brains are particularly susceptible to the stressor of poverty with long-term effects of deprivation on their brain development.

This work is instructive because it underscores that effects of austerity and economic instability are not merely transitory. As an example of work in this area, Noble et al. (2005), using MRIs to scan the brains of Philadelphia public-school children, found that the brains of those with higher family income and more parental education have larger surface areas than their poorer, less-educated peers. The strongest correlation is in brain regions associated with language and executive functioning. Children from families making less than $\$ 25000$ have 6 percent less brain surface area than peers in families making $\$ 150000$ or more. They found that small increases in family income have a much larger impact on the brains of the poorest children than similar increases among wealthier children. $^{2}$

It bears reiterating that the gendered and racialized effects of crisis and austerity are not temporary or short-run. Rather, they have long-run effects on an economy's labor productivity (Seguino 2012). This insight has yet to be incorporated into PK macro models of longrun growth. In those models, productivity growth is typically Kaldorian, depending on the Verdoorn effect and capital investment, but ignoring the role of human capacities as a complement to capital, and the gendered and racialized factors that influence human capacities.

\section{Lesson 2 Public investment can be designed so as to reduce inter-group inequalities.}

Several Kaleckian macro models incorporate the role of government spending and thus fiscal policy, ${ }^{3}$ but do not analyse the effects of different types of spending. In recent research, FEs have focused attention on government spending on infrastructure. They have further differentiated between the effects of physical infrastructure spending and social infrastructure spending in models and empirical work (Seguino 2012; de Henau/Himmelweit 2016; Braunstein et al. 2018; Onaran et al. 2018). ${ }^{4}$ While the importance of physical infrastructure spending for growth is well known, social infrastructure spending is a newer concept that refers to spending that improves the fundamental social, intellectual, and emotional

2. See also Noble et al. (2015) for further study of the link between socio-economic status and children's brain development and reference to this burgeoning literature.

3. See, for example, Dutt (2013), Palley (2013), and Obst et al. (2016).

4. For an in-depth review of the gender and growth literature, see Seguino (2019). 
skills, and the health of individuals - or level of human development - a country relies on for its economy to function (Campbell et al. 2013; Elson 2016; Himmelweit 2016).

Both physical and social infrastructure spending have an investment quality insofar as they 'crowd in' private investment and generate a stream of returns into the future. But unlike physical infrastructure - such as bridges, roads, and telecommunications systems - which tend to be publicly owned, social infrastructure is embodied in people and is enhanced via social spending by governments. Investments in people's capabilities are theorized to have a public-goods quality with positive spillover effects on economy-wide productivity. Such investments are therefore more properly classified as infrastructure spending rather than government current consumption or even simply human-development expenditures.

Both physical and social infrastructure spending can reduce gender and racial inequality, and via that transmission mechanism, stimulate long-run growth - due to both the immediate effect on aggregate demand and via the long-run effect on labor productivity. Public investment can also be a tool to achieve full employment, reducing gender and racial competition over scarce jobs (Antonopoulos et al. 2011; De Henau/Himmelweit 2016; İlkkaracan et al. 2015; Bargawi/Cozzi 2017).

A number of empirical studies have identified a positive link between physical infrastructure spending and gender equality. Most of these are focused on developing countries where poor infrastructure (roads, electricity, sanitation, and water) result in women spending enormous amounts of time on unpaid work to care for the family, limiting their ability to engage in paid work, which would otherwise generate income that could improve children's well-being. ${ }^{5}$

Recent research also shows that social infrastructure spending can promote gender equality in employment. Because women are more likely to be employed in social service activities or the paid-care sector of the economy, public spending in this area can narrow gender employment gaps. Several recent studies quantify the differential effect of publicsector spending on social as compared to physical infrastructure. De Henau/Himmelweit (2016) analyse the effect of a public investment of 2 percent of GDP to either the care or construction sector (representing social and physical infrastructure spending, respectively) in a number of European countries. While both types of spending generate substantial positive employment effects, investing in the care sector would generate roughly twice as many jobs as those targeted to the construction sector, and as a result would have the beneficial effect of reducing gender inequality. They find three key effects of investments in the care sector. In the short term, women's unpaid work falls, and more paid jobs are created. In the medium term, wages in the care sector rise, and the gender wage gap narrows. In the longer term, there is a stimulus to productivity growth due to the positive impact of this type of spending on human capacities. ${ }^{6}$

Empirical analyses are buttressed by Onaran et al.'s (2018) Kaleckian-type macro model that accounts for the role of the gender division of labor and the effect of investments in human capacities on growth. They model productivity growth on the supply side of the economy as a function of public physical and social infrastructure spending, household spending in the social sector, and unpaid domestic labor. This general modeling approach should be familiar to PKs and is a good introduction to how to integrate gender into such models. Moreover, coupled with the empirical evidence, this approach can help policy-engaged academics contribute to policy discussions on how to allocate fiscal spending in ways that achieve more than stimulus to short-run demand by also addressing intergroup inequalities.

5. See, for example, Fontana/Natali (2008).

6. See also Antonopoulos et al. (2011) and İlkkaracan et al. (2015). 
Feminists have also contributed to the debate about whether governments can afford social spending, which continues to be conceived of as discretionary spending rather than an investment. Under current fiscal discipline rules, many countries are assumed to lack sufficient fiscal space to undertake public investment. In particular, the degree of space is circumscribed by limits placed on a country's public debt relative to GDP. The current approach to establishing debt ceilings defines fiscal sustainability for the short term, an approach that ignores the interaction between fiscal policy and growth over the longer term. This leads to an underestimation of the long-term payback of public investment that could be debt-financed. ${ }^{7}$ Relatedly, current guidelines for assessing fiscal space and sustainability ignore what the fiscal space is used for. Most budgets classify current and capital budgets separately, but this distinction is not made when evaluating fiscal deficits. The result is restrictive fiscal targets, and this has led to a decline in public-investment-GDP ratios in many countries (Roy et al. 2009).

The challenge is for heterodox economists to reframe public expenditures by recognizing their investment character. Some of the benefits are more immediate, but many are evident only in the longer run. The time frame for generating measurable returns to this type of spending (and thus in many cases borrowing) may be as long as five to ten years. By that time, appropriate public investments will have begun to expand the productive base of the economy, generating (taxable) incomes with which to pay down the debt. Such investments then are both fiscally sound and sustainable. The task then is to develop alternative criteria for determining the appropriate fiscally sustainable level of public investment that takes into account the medium- and long-run economic benefits of such expenditures.

\section{Lesson 3 It's time to reconceptualize the macroeconomic roles of monetary and fiscal policy.}

FEs, along with other heterodox economists, have critiqued mainstream inflation theory and monetary policy. Epstein/Yelden (2009), for example, explore the dominant neoclassical monetary policy framework, based on inflation targeting. They underscore the mainstream's abandonment of full employment as a policy goal in favor of low inflation. Empirical research shows that the result is higher unemployment that disproportionately hurts women and people of color (Carpenter/Rodgers 2004; Braunstein/Heintz 2008; Seguino/Heintz 2012).

The main critique advanced by FEs is that monetary policies are narrowly designed to reduce aggregate demand as a way to curtail inflation, even though in many cases, inflation has supply-side origins. In developing countries, for example, inflation is linked to low productivity due to ill health (resulting from, for example, HIV/AIDs), poor infrastructure, and agricultural shocks. In rich countries, both food and energy costs contribute heavily to inflation. And more generally, in open economies, the volatility of exchange rates between a country and its main trading partners can contribute to inflation.

Epstein (2015) has advanced the view that central banks should adopt a real targeting approach whereby priority targets are identified - such as employment, affordable housing, investment, and inter-group equality. With these goals in mind, central banks would benefit from relying on a broader monetary policy toolkit. For example, Pollin et al. (2006) propose the use of asset-based reserve requirements (ABRRs) to reach priority groups. ABRRs could be designed to require private banks to choose to either allocate a portion of their lending to priority groups to reduce inequality or to place those funds in a non-interest-bearing reserve account.

7. In this discussion, I leave aside debates on modern monetary theory. 
What emerges from the discussion of fiscal and monetary policy is the perhaps heretical proposition that a role reversal is in order. That is, instead of monetary policy focusing on inflation, its target should be focused on the real economy - in particular, increased employment (and other substantive goals like housing and investment). Monetary policy of this kind also has the salutatory effect of reducing job competition that fuels racial and gender animosity. In contrast, fiscal policy could more effectively address supply-side causes of inflation. By targeting physical infrastructure investment which 'crowds in' private-sector investment as well as social-infrastructure investments that promote human capacities and economic stability, fiscal policy can also improve productivity growth, lowering unit labor costs and thus inflation.

\section{CONCLUSION}

The many contributions of PK economists to understanding the causes of the global crisis that began in 2008 could be enhanced by integrating the research of FEs and SEs. These groups have produced a body of work analysing trends in inter-group and intra-class inequality that led up to the crisis and the distribution of the negative effects of the crisis by class, race, and gender. Further, this body of work has assessed the potential for fiscal and monetary policy to promote greater equality while reducing intra-class competition and conflict. As stratification economics and feminist economics highlight, the period prior to the crisis witnessed the downward harmonization of men from the dominant racial group toward (but not to) the economic condition of women and racial/ethnic subordinate groups. Moreover, the effects of the crisis were not distributionally neutral among the working class, with a heavy burden carried by women and racial/ethnic subordinate groups. At a minimum, the stratification and feminist lenses highlight the inadequacy of treating working-class outcomes as homogenous across groups, with implications for macro models.

Macro-level policies and phenomena that differentially affect women and people of color have feedback effects on the macroeconomy. The feminist research in this area is well developed, with evidence demonstrating the negative long-run effects of worsened gender equality on long-run productivity growth. This is due in part to women's exclusion from good jobs, which holds down men's wages, along with the negative effect of economic crisis and government cutbacks on social spending, which impedes social reproduction. Brain neuroscience research underscores how long-lasting those negative effects are. Cuts disproportionately affect children in low-income households, impeding brain development with life-long effects on labor productivity.

Fiscal policies that target physical and infrastructure spending can, however, stimulate growth by reducing women's unpaid-care burden and increasing paid employment in female-dominated sectors. With evidence that women tend to spend a larger share of their income on children than men, focused spending on infrastructure can improve women's relative well-being and that of racial/ethnic subordinate groups, boosting investments in children and long-run productivity growth. This spending, which has an investment quality insofar as it yields a stream of returns into the future, would imply the importance of reformulating what we mean by fiscal space - and thus, the sustainability of public-sector deficits.

Monetary policy, too, requires reformulation. Despite the many supply-side causes of inflation, central banks in the neoliberal era have tended to respond with a single policy instrument in order to contract aggregate demand. Heterodox economists have identified alternative central-bank tools that would allow for more targeted effects of monetary policy - in particular, to promote employment. Both the stratification economics and 
feminist economics research suggests that in fact the targets of fiscal and monetary policy might well be switched - with fiscal policy used to address productivity growth, with salutatory effects on inflation, while monetary policy is used to stimulate employment growth and other real (as compared to monetary) targets.

For some PK macroeconomists, gender and racial inequality and the impact of policies on children and long-run productivity growth may appear to be outside their realm of focus. They are encouraged to resist the temptation to focus their sights too narrowly. Just as class dynamics have macroeconomic implications, so too do gender and race. The effects are not only on the demand side, but also on the supply side of the economy with important implications for fiscal and monetary policies that ensure a path to equity-led growth.

\section{REFERENCES}

Agénor, P.-R, Canuto, O., da Silva, L.P. (2010): On gender and growth: the role of intergenerational health externalities and women's occupational constraints, World Bank Policy Research Working Paper No 5492.

Almond, D., Currie, J. (2010): Human capital development before age five, in: Ashenfelter, O., Card, D. (eds), Handbook of Labor Economics, Vol. 4, Part B, Amsterdam: North Holland, $1315-1486$.

Antonopoulos, R., Masterson, T., Zacharias, A. (2011): Investing in care: a strategy for effective and equitable job creation, in: Antonopoulos, A. (ed.), Gender Perspectives and Gender Impacts of the Global Economic Crisis, London: Routledge, 47-72.

Bahçe, K., Secil, A., Memiş, E. (2013): Estimating the impact of the 2008-09 economic crisis on work time in Turkey, in: Feminist Economics, 19(3), 181-207.

Bargawi, H., Cozzi, G. (2017): Making the case for a gender-aware, investment-led recovery for Europe, in: Bargawi, H., Cozzi, G., Himmelweit, S. (eds), Economics and Austerity in Europe, London: Routledge, 137-154.

Benería, L., Feldman, S. (eds) (1992): Unequal Burden: Economic Crisis, Persistent Poverty, and Women's Work, Boulder, CO: Westview Press.

Berik, G., Kongar, E. (2013): Time allocation of married mothers and fathers in hard times: the 2007-09 US recession, in: Feminist Economics, 19(3), 208-237.

Blecker, R., Seguino, S. (2002): Macroeconomic effects of reducing gender wage inequality in an export-oriented, semi-industrialized economy, in: Review of Development Economics, 6(1), $103-119$.

Blumberg, R.L. (1984): A general theory of gender stratification, in: Sociological Theory, 2, 23-101.

Blumer, H. (1958): Race prejudice as a sense of group position, in: Pacific Sociological Review, 1(1), 3-7.

Braunstein, E., Heintz, J. (2008): Gender bias and central bank policy: employment and inflation reduction, in: International Review of Applied Economics, 22(2), 173-186.

Braunstein, E., van Staveren, I., Tavani, D. (2011): Embedding care and unpaid work in macroeconomic modeling: a structuralist approach, in: Feminist Economics, 17(4), 5-31.

Braunstein, E., Seguino, S., Altringer, L. (2018): Estimating the role of social reproduction in economic growth, Working Paper, Colorado State University and University of Vermont.

Campbell, J., Elson, E., McKay, A. (2013): The Economic Case for Investing in High-quality Childcare and Early Years of Education, WiSE Briefing Sheet, November, Glasgow: Glasgow Caledonian University, URL: www.gcu.ac.uk/media/WiSEBriefingPaperNov13.pdf.

Carpenter, S., Rodgers, W. (2004): Disparate labor market impacts of monetary policy, in: Journal of Policy Analysis and Management, 23(4), 813-830.

Carr, M., Jayadev, A. (2015): Relative income and indebtedness: evidence from panel data, in: Review of Income and Wealth, 61(4), 759-772.

Case, A., Deaton, A. (2015): Rising morbidity and mortality in midlife among white non-Hispanic Americans in the 21st century, in: Proceedings of the National Academy of Sciences of the United States of America, 112, 15078-15083. 
Currie, J., Duque, V., Garfinkel, I. (2015): The great recession and mother's health, in: Economic Journal, 125(588), 311-346.

Cynamon, B., Fazzari, S. (2015): Rising inequality, demand, and growth in the US economy, URL: https://ssrn.com/abstract=2570506 or http://dx.doi.org/10.2139/ssrn.2570506.

Darity, W., Jr, Mason, P., Stewart, J. (2006): The economics of identity: the origin and persistence of racial identity norms, in: Journal of Economic Behavior and Organization, 60(3), 283-305.

Darity, W., Hamilton, D., Mason, P., Price, G., Dávila, A., Mora, M., Stockly, S., Warren, D., Wong, F., Holmberg, S. (2017): Stratification economics: a general theory of intergroup inequality, in: The Hidden Rules of Race: Barriers to an Inclusive Economy, Cambridge, UK: Cambridge University Press, 35-51.

De Henau, J., Himmelweit, S. (2016): Developing a macro-micro model for analysis of gender impacts of public policy, Paper presented at 'Gender and Macroeconomics: Current State of Research and Future Directions,' Levy Economics Institute, Bard College, New York City, 9 March.

Doss, C. (2013): Bargaining and resource allocation in developing countries, in: World Bank Research Observer, 28(1), 52-78.

Dutt, A.K. (2013): Government spending, aggregate demand, and economic growth, in: Review of Keynesian Economics, 1, 105-119.

Dymski, G., Hernandez, J., Mohanty, L. (2013): Race, gender, power, and the US subprime mortgage and foreclosure crisis: a meso analysis, in: Feminist Economics, 19(3), 124-151.

Elson, D. (1995): Male bias in macro-economics: the case of structural adjustment, in: Elson, D. (ed.), Male Bias in the Development Process, 2nd edn, Manchester: Manchester University Press, 164-190.

Elson, D. (2016): Gender budgeting and macroeconomic policy, in: Campbell, J., Gillespie, M. (eds), Feminist Economics and Public Policy, London: Routledge, 27-37.

Epstein, G. (2015): Development central banking: a review of issues and experiences, ILO Employment Working Paper No 182.

Epstein, G., Yelden, E. (eds) (2009): Beyond Inflation Targeting: Monetary Policy for Employment Generation and Poverty Reduction, Cheltenham, UK and Northampton, MA: Edward Elgar Publishing.

Folbre, N. (1986): Hearts and spades: paradigms of household economics, in: World Development, $14(2), 245-255$.

Folbre, N. (1994): Who Pays for the Kids? Gender and the Structures of Constraint, London and New York: Routledge.

Fontana, M., Natali, L. (2008): Gendered patterns of time use in Tanzania: public investment in infrastructure can help, Paper prepared for the IFPRI Project on Evaluating the Long-Term Impact of Gender-Focused Policy Interventions.

Fukada-Parr, S., Heintz, J., Seguino, S. (eds) (2015): Critical and Feminist Perspectives on Financial and Economic Crises, New York and London: Routledge.

Haddad, L., Hoddinott, J., Alderman, H. (eds) (1997): Intrahousehold Resource Allocation in Developing Countries, Baltimore, MD: Johns Hopkins University Press.

Henrici, J., Helmuth, A., Zlotnick, F., Hayes, J. (2010): Women in poverty during the Great Recession, IWPR Briefing Paper.

Himmelweit, S. (2016): Childcare as an investment in infrastructure, in: Campbell, J., Gillespie, M. (eds), Feminist Economics and Public Policy, London: Routledge, 83-93.

İlkkaracan, I., Kim, L., Kaya, T. (2015): The impact of public investment in social care services on employment, gender equality, and poverty: the Turkish case, Istanbul Technical University Women's Studies Center and the Levy Economics Institute, URL: http://www.levyinstitute. org/pubs/rpr_8_15.pdf.

Karamessini, M., Rubery, J. (2013): Women and Austerity: The Economic Crisis and the Future for Gender Equality, Abingdon and New York: Routledge IAFFE Advances in Feminist Economics.

Kucera, D., Milberg, W. (2000): Gender segregation and gender bias in manufacturing trade expansion: revisiting the 'Wood Asymmetry,' in: World Development, 28(7), 1191-1210.

Noble, K., Norman, M., Farah, M. (2005): Neurocognitive correlates of socioeconomic status in Kindergarten Children, in: Developmental Science, 8(1), 74-87. 
Noble, K., Houston, S., Brito, N., Bartsch, H., Kan, E., Kuperman, J., Akshoomoff, N., Amaral, D., Bloss, C., Libiger, O., Schork, N., Murray, S., Casey, B., Chang, L., Ernst, T., Frazier, J., Gruen, J., Kennedy, D., Van Zijl, P., Mostoofsky, S., Kaufmann, W., Kenet, T., Dale, A., Jernigan, T., Sowell, E. (2015): Family income, parental education and brain structure in children and adolescents, in: Nature Neuroscience, 18, 773-778.

Obst, T., Onaran, O., Nikolaidi, M. (2016): A post Kaleckian analysis of the effect of income distribution, public spending and taxes on growth, investment, and budget balance: the case of Europe, Greenwich Papers in Political Economy.

Onaran, O., Oyvat, C., Fotopoulou, E. (2018): Gendering macroeconomic analysis and development policy: the role of labour market and fiscal policies for gender equitable development, Working Paper, University of Greenwich, Greenwich Political Economy Research Centre (GPERC).

Ortiz, I., Cummins, M. (2013): The age of austerity: a review of public expenditures and adjustment measures in 181 countries, Initiative for Policy Dialogue and the South Centre Working Paper.

Palley, T. (2013): Cambridge and neo-Kaleckian growth and distribution theory: comparison with an application to fiscal policy, in: Review of Keynesian Economics, 1, 79-104.

Pollin, R., Epstein, G., Heintz, J., Ndikumana, L. (2006): An Employment-Targeted Economic Program for South Africa, Cheltenham, UK and Northampton, MA: Edward Elgar Publishing.

Roy, R., Heuty, A., Letouzé, E. (2009): Fiscal space for public investment: towards a human development approach, in: Roy, R., Heuty, A. (eds), Fiscal Space: Policy Options for Financing Human Development, London: Earthscan Publications, 67-92.

Seguino, S. (2010a): Gender, distribution, and balance of payments constrained growth in developing countries, in: Review of Political Economy, 22(3), 373-404.

Seguino, S. (2010b): The global economic crisis, its gender and ethnic implications, and policy responses, in: Gender and Development, 18(2), 179-199.

Seguino, S. (2012): Macroeconomics, human development, and distribution, in: Journal of Human Development and Capabilities, 13(1), 59-83.

Seguino, S. (2016): Global trends in gender equality, in: Journal of African Development, 18(1), 1-30.

Seguino, S. (2019): Engendering macroeconomic theory and policy, in: Feminist Economics, doi: 10.1080/13545701.2019.1609691.

Seguino, S., Braunstein, E. (2018): The costs of exclusion: gender job segregation, structural change, and the labour share of income, in: Development and Change, doi: 10.1111/dech.12462.

Seguino, S., Heintz, J. (2012): Monetary tightening and the dynamics of race and gender stratification in the US, in: American Journal of Economics and Sociology, 71(3), 603-638.

Standing, G. (1989): Global feminization through flexible labor, in: World Development, 17(7), $1077-1095$.

Stockhammer, E. (2015): Rising inequality as a cause of the present crisis, in: Cambridge Journal of Economics, 39(1), 935-958.

Wall, H. (2009): The 'man-cession' of 2008-2009: big, but it's not great, in: The Regional Economist, 18(4), 4-9.

Women's Budget Group (2013): The impact on women of the coalition government's spending round 2013, URL: http://wbg.org.uk/wp-content/uploads/2013/10/WBG-Analysis-June2013-Spending-Round.pdf.

Women's Budget Group (2017): Intersecting inequalities: the impact of austerity on black and minority ethnic women in the UK, London: Women's Budget Group and Runnymede Trust. 